\title{
Effects of irrigation and planting geometry on cotton (Gossypium hirsutum L.) fiber quality and seed composition
}

\author{
PINNAMANENI Srinivasa R. ${ }^{*}$ (D, ANAPALLI Saseendran S. ${ }^{1}$, SUI Ruixiu ${ }^{1}$, BELLALOUI Nacer ${ }^{2}$ and REDDY Krishna N. ${ }^{3}$
}

\begin{abstract}
Background: Cotton fiber quality and seed composition play vital roles in the economics of cotton production systems and the cottonseed meal industry. This research aimed to examine the effects of different irrigation levels and planting geometries on fiber quality and seed composition of cotton (Gossypium hirsutum L.). We conducted a 2-year study in 2018 and 2019 in a warm, humid area in the Southeast United States on Dundee silt loam soil. There were three irrigation treatments in the study. The treatments included irrigating every furrow, or full irrigation $(F I)$, every alternate furrow, or half irrigation $(H I)$, and no irrigation, or rain-fed (RF). Planting geometries were on ridges spaced $102 \mathrm{~cm}$ apart and either a single-row (SR) or twin-rows (TR).

Results: The results of high-volume instrument (HVI), advanced fiber information systems (AFIS) and near-infrared reflectance spectroscopy (NIRS) showed that irrigation and planting treatments played a significant role in fiber quality and seed composition. Across irrigation treatments, significant differences were seen in fiber properties, including fineness, maturity ratio, micronaire, neps, short fiber, strength, uniformity, upper half mean length (UHML), upper quartile length by weight (UQLw), and yellowness (+b). Irrigation and planting geometry (PG) had a significant effect on micronaire, strength, and UHML while their interaction was significant only for micronaire. The micronaire was negatively affected by irrigation as FI-SR, FI-TR, HI-SR, and HI-TR recorded 11\% 12\% lower over the RF-SR and TR treatments. The PG played a minor role in determining fiber quality traits like micronaire and nep count. Irrigation treatments produced significantly lower (3\% 4\%) protein content than rain-fed, while oil content increased significantly (6\% 10\%).

Conclusions: The study results indicate a potential for improving cotton fiber and seed qualities by managing irrigation and planting geometries in cotton production systems in the Mississippi (MS) Delta region. The HI-TR system appears promising for lint and seed quality.
\end{abstract}

Keywords: Cotton, Fiber quality, Seed composition, Micronaire, Fiber length

\section{Introduction}

The United States of America (USA) is among the countries producing the highest-quality cotton in the world (https:// www.ers.usda.gov/topics/crops/cotton-wool/cotton-sector-at -a-glance/). Comprehensive data of cotton fiber and cottonseed qualities are essential information required for maintaining high-quality cotton production in response to

\footnotetext{
* Correspondence: sri.pinnamaneni@usda.gov

'USDA-ARS, Sustainable Water Management Research Unit, Stoneville, MS 38776, USA

Full list of author information is available at the end of the article
}

changing technology and agronomic management practices (Roth 2010). In the state of Mississippi (MS), USA, cotton is grown in over $0.25 \mathrm{Mha}$ with an estimated production of $1.46 \mathrm{M}$ bales (USDA-NASS 2019). In this region, traditionally, cotton is planted in a single row (SR) on the raised beds spaced between $96 \mathrm{~cm}$ and $102 \mathrm{~cm}$ apart. Currently, > 60\% of the cotton acreage is irrigated (Kebede et al. 2014). Planting the same number of seeds in twin rows (TR, two rows spaced between $18 \mathrm{~cm}$ and $38 \mathrm{~cm}$ on seedbeds centered on the raised beds spaced between $96 \mathrm{~cm}$ and $102 \mathrm{~cm}$ ) compared with SR has been reported to enhance yield

(c) The Author(s). 2021 Open Access This article is licensed under a Creative Commons Attribution 4.0 International License, which permits use, sharing, adaptation, distribution and reproduction in any medium or format, as long as you give appropriate credit to the original author(s) and the source, provide a link to the Creative Commons licence, and indicate if changes were made. The images or other third party material in this article are included in the article's Creative Commons licence, unless indicated otherwise in a credit line to the material. If material is not included in the article's Creative Commons licence and your intended use is not permitted by statutory regulation or exceeds the permitted use, you will need to obtain permission directly from the copyright holder. To view a copy of this licence, visit http://creativecommons.org/licenses/by/4.0/. 
and net returns in soybean and cotton (Pinnamaneni et al. 2020; Reddy and Boykin 2010).

Reliable fiber quality measurement became available with the advent of the high volume instrument (HVI) in the late 1960s and advanced fiber information system (AFIS) in the 1980s. Cotton researchers, since the 1960s, have used HVI fiber measurements as their primary source of data while making selections and advancing plant populations for fiber quality improvement. The AFIS helps predict spinning performance and yarn quality as it completely characterizes the within-sample distribution of the fiber length of individual fibers. The HVI method had fewer data available such as fiber length (e.g., upper half mean length, UHML), micronaire, strength, trash, uniformity index, and yellowness $(+b)$. In contrast, the AFIS method offers finer details of fiber such as dust, fineness, length by number (Ln), length by weight, nep, maturity ratio, short fiber content by number (SFCn) and weight, upper quartile length by weight (UQLw). Fiber quality is a critical attribute in determining cotton profitability. Each bale (around $228 \mathrm{~kg}$ of lint) of cotton produced in the USA goes through the HVI fiber quality assessment controlled by the United States Department of Agriculture-Agricultural Marketing Service (USDA-AMS). The fiber quality properties such as short fiber stickiness, trash contents, color, fiber length, and micronaire are determiners in the commercial system for cotton pricing and marketing (Bowman and Ethridge 1992; Ge et al. 2008). The U.S. textile industry has gradually adopted more open-end rotor spinning, with a much higher turnover rate, increasing the importance of cleanliness and strength. At the same time, fiber length and micronaire are less critical. Many interacting factors drive fiber quality, including cultivar choice, crop management, and climate during the season. When fiber quality is low, producers assume that there was cotton boll exposure to adverse events, such as untimely rain, insect secretions, or dust while in the field. These environmental factors are often beyond the control of the growers (Pettigrew 2010).

Irrigation affects lint quality in multiple ways, particularly during the fiber elongation phase, including ginning percentage, fiber length, strength, uniformity, fineness, micronaire, and SFC (Balkcom et al. 2006; Basal et al. 2009; Feng et al. 2014; Pettigrew 2004; Pettigrew and Dowd 2011; Sui et al. 2017; Witt et al. 2020; Zhang et al. 2016). In a study conducted in the MS Delta, irrigation improved cotton yield and fiber length (Sui et al. 2017). A $1.5 \mathrm{~m}$ row-spaced cotton matured more slowly than cotton rows with $1.0 \mathrm{~m}$ spacing, which led to more durable and longer cotton fibers with overall better fiber quality (Bartimote et al. 2017). Stephenson et al. (2011) reported that planting patterns did not affect fiber length (28.7 mm), micronaire (4.3), strength (287 288 kN $\mathrm{m} \cdot \mathrm{kg}^{-1}$ ), or uniformity (83.5 84.3\%). Also, fiber length (28.5 28.7 mm), micronaire (4.2 4.4), strength (286 290 $\left.\mathrm{kN} \cdot \mathrm{m} \cdot \mathrm{kg}^{-1}\right)$, or uniformity $(83.6 \sim 84.2 \%)$ were not affected by plant density. Previous work indicated that plant density slightly affected micronaire while it does not affect either fiber strength or uniformity (Pettigrew and Dowd 2011). Darawsheh et al. (2009) observed decreased fiber length and micronaire with increased plant densities, but fiber strength and uniformity were not affected. A 2-year study in the MS Delta on fiber quality demonstrated that cotton produced in $38-\mathrm{cm}$ single and $38-\mathrm{cm}$ twin rows on $102 \mathrm{~cm}$ beds was equal to or better than cotton propagated in conventional $102 \mathrm{~cm}$ rows (Boykin and Reddy 2010).

Cottonseed processing primarily yields four products: linters, hulls, oil, and meal (i.e., protein). While the linters and hulls have commercial uses, the oil and protein attract more attention due to their sheer value. The dairy industry particularly values the whole seed due to its high protein (35\%) and oil (30\%) content to feed ruminants, and its use has gradually increased over the years (Arieli 1998). Historically, the main objective of cotton breeding is to improve fiber yield and lint quality, while research on seed composition is less of a priority. There have been documented correlations for protein, oil, and oil iodine value with rainfall and temperature patterns from data recorded across several locations and years (Stansbury et al. 1956). The recent trials' data revealed significant associations between fatty acid composition and the prevailing weather conditions (Dowd 2015). There is copious genetic variability in seed traits, which suggests a potential for future compositional improvements, but our understanding is limited to how environmental factors alter seed composition.

A recent study conducted in the MS Delta demonstrated that using the TR-PG enhanced cotton lint yield by $10.62 \%$ in 2018 and $17.62 \%$ in 2019 (Pinnamaneni et al. 2020). Such yield enhancement on the lint quality and seed composition under different irrigation levels is poorly understood. Many studies on the individual effects of irrigation and PG on cotton yield, fiber quality, and seed composition exist, but researches examining their interactions are less common. Also, researches conducted on PG or irrigation effects on fiber quality emphasized either HVI data or AFIS data, rather than combined analysis. The objectives of this study were to examine the effects of three irrigation levels (RF, FI, and $\mathrm{HI}$ ) and two planting geometries (SR and TR) and their interactions on (i) cotton fiber quality, (ii) cottonseed quality.

\section{Materials and methods}

\section{Cultural practices}

We conducted a 2-year (2018-2019) field experiment with cotton (cv. FiberMax1944GLB2) at the research 
farm of the USDA-ARS Crop Production Systems Research Unit in Stoneville, MS, USA $\left(33^{\circ} 42^{\prime} \mathrm{N}, 90^{\circ} 55^{\prime}\right.$ W, elevation: $32 \mathrm{~m}$ above mean sea level). The soil was a Dundee silt loam (fine silty, mixed, active, thermic Typic Endoaqualfs) with $0.87 \%$ organic matter, $0.44 \%$ carbon, $0.06 \%$ nitrogen, $50 \mathrm{mg} \cdot \mathrm{kg}^{-1} \mathrm{P}, 220 \mathrm{mg} \cdot \mathrm{kg}^{-1} \mathrm{~K}, 348$ $\mathrm{mg} \cdot \mathrm{kg}^{-1} \mathrm{Mg}, 2057 \mathrm{mg} \cdot \mathrm{kg}^{-1} \mathrm{Ca}, 2.1 \mathrm{mg} \cdot \mathrm{kg}^{-1} \mathrm{Zn}, 9.1$ $\mathrm{mg} \cdot \mathrm{kg}^{-1} \mathrm{~S}, 16.6 \mathrm{CEC}$, and $1.28 \mathrm{~g} \cdot \mathrm{cm}^{-3}$ bulk density averaged across $60 \mathrm{~cm}$ soil depth. As measured in this study, the field saturated hydraulic conductivity $\left(K_{\mathrm{fs}}\right)$ of the soil ranged from 0.41 to $1.22 \mathrm{~cm} \cdot \mathrm{h}^{-1}$. Field preparation consisted of sub-soiling, disking, and bedding in the fall. We refurbished the raised-ridge seedbeds before planting in the spring, and we smoothed the tops of the seedbeds as needed to plant cotton in SR and TR planting geometries. Glyphosate (in a.i.) at $1.12 \mathrm{~kg} \cdot \mathrm{hm}^{-2}$ was applied about 1 month before cotton planting to kill the existing weeds. We used a 7300 vacuum planter (John Deere, East Moline, IL) to plant in the SR PG. We completed the TR PG using a Monosem NG +3 TR vacuum planter (ATI, Inc., Monosem, Lenexa, KS) set to achieve a plant population density of 120000 plants.hm ${ }^{-2}$. We estimated actual plant populations at harvest by counting plants in a $1 \mathrm{~m}^{2}$ area in the two center rows at three randomly selected locations in each plot. Fertilizer application, weed control, and insect control programs were standard for cotton production. Isolated weed occurrences were hand hoed as needed.

Cotton cv. FiberMax1944GLB2, a medium-maturing Bt-transgenic (Cry1Ac and Cry2Ab genes) variety with broad adaptation, possessing in-plant tolerance to glyphosate, liberty, and glufosinate (BASF), was planted on May $8^{\text {th }}, 2018$, and May $16^{\text {th }}, 2019$. We designed the experiment in a split-plot arrangement of treatments in a randomized complete block design with six replications. We designated the three irrigation regimes full irrigation (FI), half irrigation (HI), and rain-fed (RF) as the main plots while subplots consisted of the two planting geometries, SR arrangement evenly spaced at $102 \mathrm{~cm}$ and TR arrangement spaced at $25 \mathrm{~cm}$ apart on $102 \mathrm{~cm}$ centered seedbeds. Each plot consisted of four SR or eight TR treatments and was $40 \mathrm{~m}$ long. We installed sensors for measuring soil-matrix water potential (Watermark sensors, Irrometer Company, Inc., Riverside, CA, USA) at soil depths of 15,30 , and $60 \mathrm{~cm}$ in selected representative plots. We scheduled irrigation based on a soil matrix potential of about $-90 \mathrm{kPa}$ at $45 \mathrm{~cm}$ soil depths, as recommended by Plumblee et al. (2019). We measured the amount of irrigation water applied in each plot during each season using a flow meter. In 2018, we applied a total of $17.5 \mathrm{~cm}$ of water in the FI treatments in five irrigation events of $3.5 \mathrm{~cm}$ each applied through every furrow on May $15^{\text {th }}$, June $21^{\text {st }}$, June $29^{\text {th }}$, July $6^{\text {th }}$, and August $4^{\text {th }}$, while the $\mathrm{HI}$ treatments received the half the amount of water on the same dates applied in every other furrow (skip furrow irrigation). The total amount of water applied in HI was about $8.85 \mathrm{~cm}$ compared with $17.5 \mathrm{~cm}$ in the FI treatment. In 2019, the total irrigation applied was 15.2 $\mathrm{cm}$ in the FI treatment in four irrigation events of $3.8 \mathrm{~cm}$ each on May $26^{\text {th }}$, June $29^{\text {th }}$, July $24^{\text {th }}$, and August $6^{\text {th }}$, while in HI treatments, we applied $7.5 \mathrm{~cm}$ of water on the same dates. We did not apply further irrigation after the cotton reached the first boll cracking stage of the growth.

During mid-to-late September each year, we defoliated the cotton using a two-step process. We initiated defoliation when approximately $65 \%$ of the bolls had opened in mid-September. We applied a mixture of 0.035 $\mathrm{kg} \cdot \mathrm{hm}^{-2}$ thidiazuron and $0.0175 \mathrm{~kg} \cdot \mathrm{hm}^{-2}$ diuron to the crop canopy in the first application. One week later, we applied a mixture of $0.035 \mathrm{~kg} \cdot \mathrm{hm}^{-2}$ thidiazuron, 0.0175 $\mathrm{kg} \cdot \mathrm{hm}^{-2}$ diuron, and $1.68 \mathrm{~kg} \cdot \mathrm{hm}^{-2}$ ethephon as a second step to complete the defoliation and facilitate the opening of the remaining unopened bolls. Approximately 2 weeks after the second defoliant application, we collected yield data by handpicking from a $1 \mathrm{~m}^{2}$ section in the two center rows at three randomly selected locations in each plot.

\section{Data collection}

We collected weather data from the Mid-South Agricultural Weather Service, Delta Research and Extension Center in Stoneville, MS. We calculated the growing degree days (GDD) using a base temperature of $10^{\circ} \mathrm{C}$ for cotton growth (Desclaux and Roumet 1996). After physiological maturity, we harvested above-ground biomass from a $1 \mathrm{~m}^{-2}$ section of the middle two-rows from each plot at three locations, avoiding the row ends. We sampled from one row for the SR pattern and two rows for the TR pattern. We used a 10-saw laboratory gin (USDA-ARS Cotton Ginning Lab, Stoneville, MS) to process seed cotton, and calculated the lint yield on a per hectare basis.

\section{Fiber quality analysis}

We collected 10 subsamples from each sample for fiber quality analysis after the lint cleaner. We used five of them for testing with AFIS and five with HVI, and analyzed all lint samples in the HVI at the USDA ARS Cotton Ginning Research Unit in Stoneville, MS., and all AFIS analysis at the Fiber and Biopolymer Research Institute, Texas Tech University, TX. We measured the fiber quality parameters with both AFIS (dust, fiber Ln, fiber Lw, fineness, maturity ratio, nep, SFCn, UQLw, and trash) and HVI instruments (fiber length, elongation, micronaire, strength, uniformity index, $+b$, Rd., and UHML). 


\section{Seed composition analysis}

We collected mature cottonseeds, acid-delinted them, and analyzed them for protein and oil contents. We ground approximately $25 \mathrm{~g}$ of seed using a Laboratory Mill 3600 (Perten, Springfield, IL). We employed near infrared spectroscopy (NIRS), according to Wilcox and Shibles (2001) and Bellaloui and Turley (2013), using a diode array feed analyzer AD 7200 (Perten, Springfield, IL) to estimate protein and oil contents. We used Perten's Thermo Galactic Grams PLS IQ software for calibrations and established the calibration equation according to AOAC methods (Association of Official Analytical Chemists, AOAC, 1990). We expressed cottonseed protein and oil on a seed dry matter basis in percentage (Bellaloui and Turley 2013).

\section{Statistical analysis}

We performed statistical analyses by analysis of variance (PROC MIXED; SAS Institute, 1996). Because all irrigation variables, planting dates, and treatments remained in their original location each year, we treated years as a repeated measurement when conducting a combined analysis across years, with the year, irrigation, PG, and their interactions as fixed effects and replication and whole plot (irrigation) as random effects. Random effects used in this model for the comparison across years were irrigation $X$ year, PG X year, and irrigation X PG X year. We separated treatment means at the $5 \%$ level of significance using Fisher's protected least significant difference (LSD) test.

\section{Results}

\section{Weather and lint yield}

The weather significantly varied during the two cropping seasons in 2018 and 2019 (Fig. 1). The period of reproductive growth and boll filling (July to September) during 2019 was warmer, with 92 GDD more than in 2018 . In general, the 2018 crop season was less wet $730.8 \mathrm{~mm}$ in 2018 and $895.9 \mathrm{~mm}$ in 2019) and had less monthly cumulative solar radiation of $19.2 \mathrm{MJ} \cdot \mathrm{m}^{-2}$ than 2019 $\left(102.4 \mathrm{MJ} \cdot \mathrm{m}^{-2}\right.$ in 2018 vs. $121.5 \mathrm{MJ} \cdot \mathrm{m}^{-2}$ in 2019$)$. However, the period of vegetative growth (May to July) in
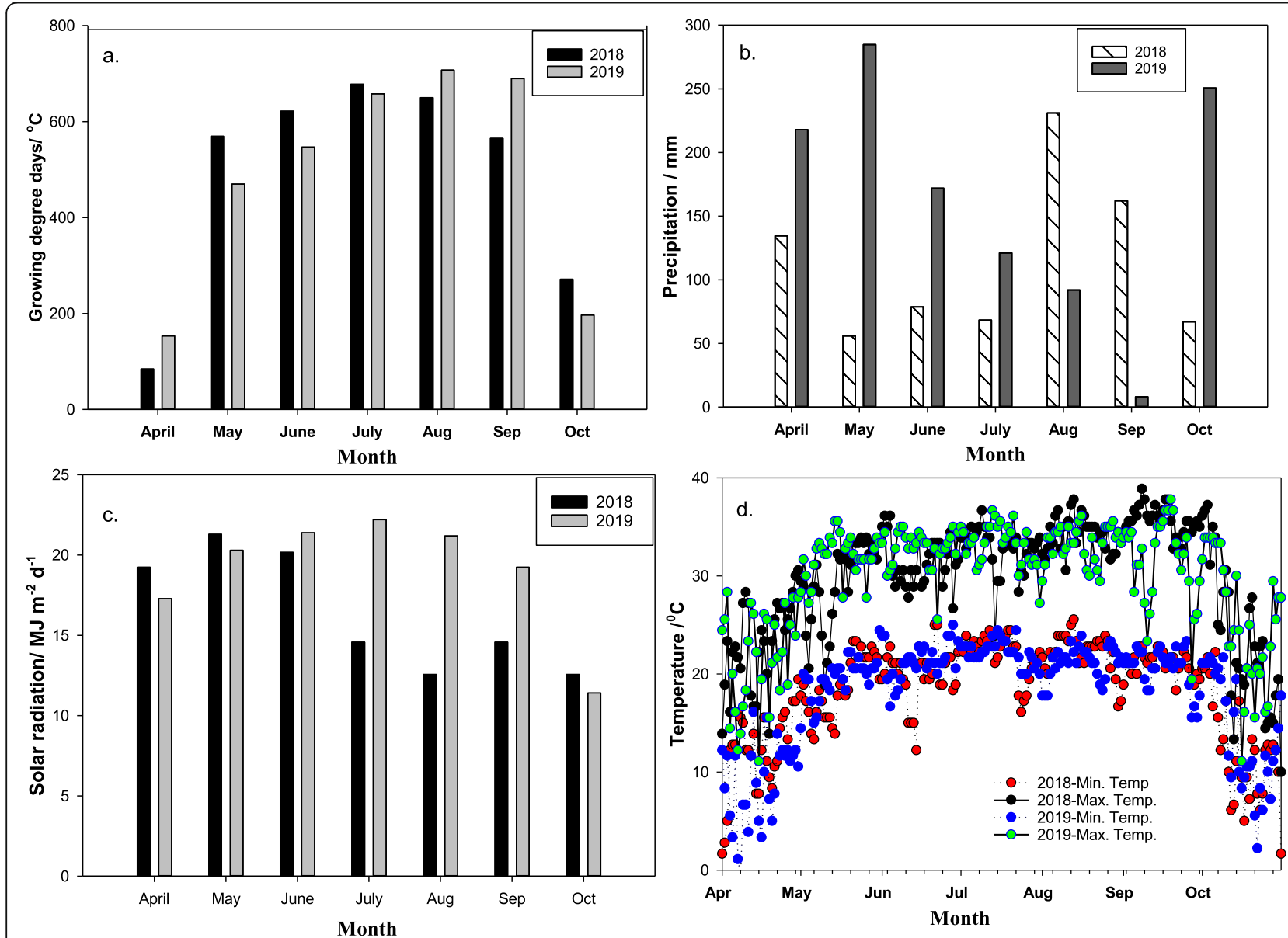

Fig. 1 Measured (a) growing degree days (GDD), (b) precipitation, (c) solar radiation, and (d) air temperature for 2018 and 2019 cotton growing seasons at Stoneville, MS 
2018 coincided with periods of lower rainfall $(203 \mathrm{~mm}$ in 2018 vs. $578 \mathrm{~mm}$ in 2019) and higher mean minimum and maximum temperatures. Hence, the analysis of variance (ANOVA) revealed year has significant interaction on most of the fiber quality and seed composition parameters (Table 1 ).

The higher lint yield in the HI treatments is probably due to optimum water availability in the active root zone. In the FI treatments, there was likely excess water around the root zone, owing to heavy precipitation events following the irrigation coinciding boll formation and developmental stages in July and August, which caused increased vegetative growth, boll drop, and immature boll formation (Feng et al. 2014; Letey and Dinar 1986) (Fig. 1b). The RF treatments with TR planting geometries had 9.34 plants $\cdot \mathrm{m}^{-2}$ and there were 7.6 plants $\cdot \mathrm{m}^{-2}$ in the RF treatments with the SR planting geometries at harvesting. The TR-PG treatment combination produced a significantly higher number of bolls (75 bolls per square meter) than the SR treatment (64 bolls per square meter) (Pinnamaneni et al. 2020).

\section{HVI measurements}

\section{Micronaire}

Micronaire represents the surface area of lint and is a measure of fiber fineness and maturity. Both irrigation and PG treatments significantly affected micronaire (Table 1). The RF treatment showed a higher micronaire value than the corresponding $\mathrm{HI}$ and FI treatments. As seen in Table 2, the TR planting geometry has consistently produced a significantly higher micronaire than SR by $3 \% \sim 7 \%$ on average. Although most of the fiber quality parameters were significantly different for the year, micronaire differences were consistent in 2018 and 2019.

\section{Fiber strength}

Fiber strength, an important parameter affecting yarn quality, was significantly affected by irrigation treatments, while the PG did not impart any significant influence (Table 1). There were no statistically significant differences in the fiber strength between the two irrigation treatments (HI and FI) in either year, but the RF treatment significantly decreased the fiber strength in both seasons, as seen in Table 2 .

\section{Uniformity}

In both treatment years, irrigation significantly affected uniformity, while PG did not impact fiber uniformity (Table 1). Among the irrigation treatments, HI produced significantly higher fiber uniformity (HI-SR: $84.3 \%$ and HI-TR: $84.2 \%$ ) than FI treatments (FI-SR: $82.8 \%$ and FITR: 83.2\%) (Tables 1 and 2). This lower fiber uniformity in the FI treatments compared with HI could result from excess water in the root zone during boll development and cracking stage, resulting in more vegetative growth as well as immature bolls formation, and in some extreme cases, boll drop.

\section{Upper half mean length (UHML)}

The UHML is a crucial trait affecting the blend properties of yarn; hence, the textile industry deems UHML to have high importance. Irrigation has a significant positive impact on UHML (Tables 1 and 2). The UHML was significantly lower in the rain-fed treatments by about $9 \%$ on average. However, like uniformity, UHML was not impacted by PG, and the differences among $\mathrm{HI}$ and FI treatments were insignificant (Tables 1 and 2).

\section{Reflectance (Rd)}

There was no significant change in $\mathrm{Rd}$ with irrigation or PG treatments (Table 1). However, there were significant differences in $\mathrm{Rd}$ between years. The mean $\mathrm{Rd}$ for all treatments in 2018 was 5.9\% higher than that of 2019. This difference in Rd between years is likely due to fluctuations in air temperature and precipitation patterns.

\section{Yellowness (+b)}

Like $\mathrm{Rd}$, +b was unaffected by irrigation and PG treatments (Table 1). However, there were significant differences in $+b$ between years. The mean of all treatments in 2018 was $7.7 \%$ higher than that of 2019. This difference between years is most likely due to differences in GDDs and precipitation patterns (Table 2).

\section{AFIS measurements Length by number (Ln)}

The Ln was significantly affected by irrigation but not by PG treatments. However, the interaction between PG and irrigation was insignificant (Table 1). The Ln value was significantly higher in the $\mathrm{HI}$ and FI treatments than the RF treatment 9 and 10\% in 2018 and 2019, respectively. The average Ln values for FI, HI, and RF were $23.5 \mathrm{~mm}, 23.4 \mathrm{~mm}$, and $21.4 \mathrm{~mm}$, respectively (Tables 1 and 2).

\section{Nep count}

Neps are measures of defects in cotton fiber. We commonly used the measurement of nep count (both size and quantity) to adjust the processing machinery to reduce or eliminate the generation of mechanical neps. Nep count represents the number of neps observed in $0.5 \mathrm{~g}$ of a cotton fiber sample. Irrigation significantly contributed to nep count, while PG or its interaction with irrigation did not influence nep count (Tables 1 and 2). On average, the HI and FI nep count were about $65 \%$ higher than that of RF cotton. 


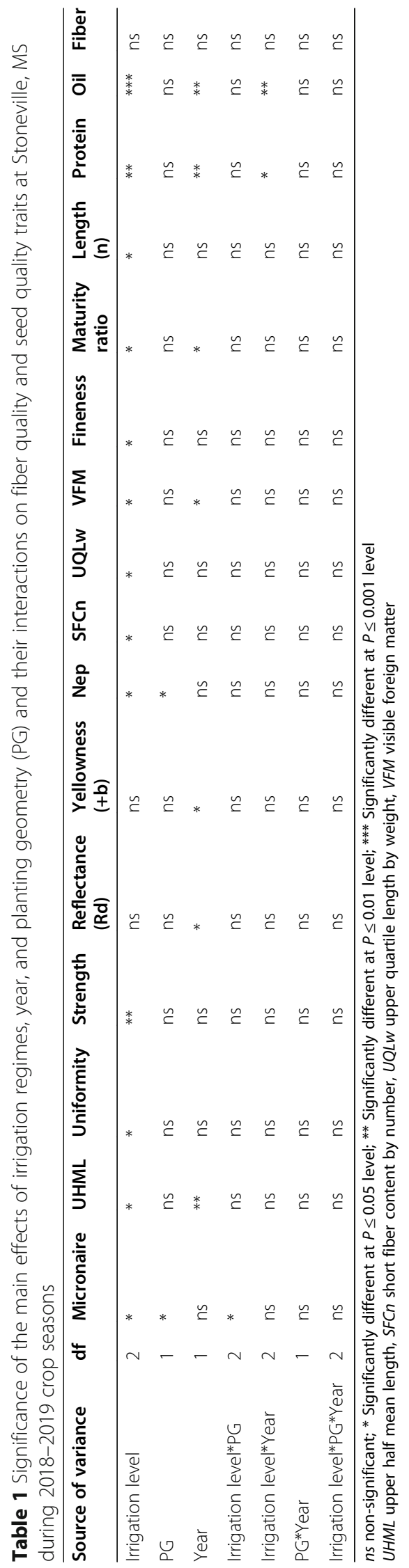


Table 2 Fiber quality characteristics of irrigation treatments ( $\mathrm{Fl}, \mathrm{HI}$, and RF) on cotton in a Dundee silt loam with single-row (SR) and twin-row (TR) planting geometries estimated by high volume instrument (HVI). Fl is full irrigation; $\mathrm{HI}$ is half irrigation; $\mathrm{RF}$ is rain-fed

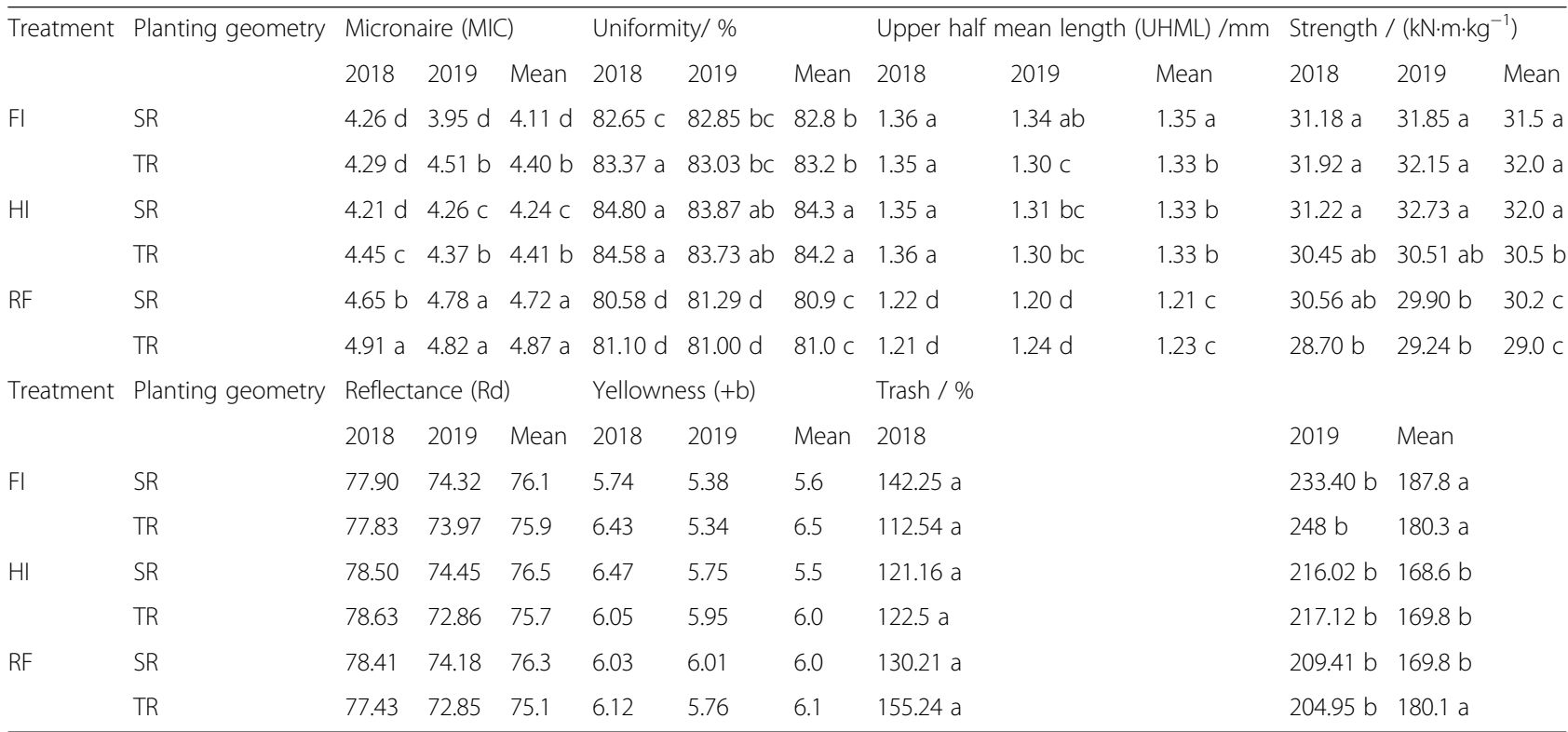

Means in each column followed by the same letter or letters are not statistically different by LSD means $(P \leq 0.05)$

\section{Short Fiber content by number (SFCn)}

The SFCn is the percentage of fibers that are shorter than $12.7 \mathrm{~mm}$. High $\mathrm{SFCn}$ values reduce the quality of yarn. There were no significant effects of irrigation and PG in both years (Table 1). However, irrigated treatments (both HI and FI) recorded numerically higher SFCn values than the RF treatment in both years.

\section{Visible foreign matter (VFM)}

Both the irrigation and the year had a significant effect on VFM, while PG did not affect VFM (Table 1). In 2018, VFM ranged between 2.5 and $3.15 \%$, while it ranged from 5.82 to $8.24 \%$ in 2019 . The RF treatments have significantly lower VFM in both years (Table 3), which is likely due to diverse weather conditions during boll development, cracking, and harvesting.

\section{Fineness}

Irrigation is detrimental to fineness, as higher fineness properties of the fiber are preferable to the processing industry (Table 1). As seen in Table 3, rain-fed cotton produces higher fiber fineness (RF-SR: 183.5 and RF-TR: $186.1 \mathrm{mtex})$, and the FI and HI treatments ranged from 170.6 to 175.4 mtex. The effect of PG and its interaction with irrigation were insignificant in both years.

\section{Maturity ratio}

The maturity ratio, a key component of fiber quality, has a significant inverse relationship with irrigation (Feng et al. 2014). Planting geometry and its interaction with irrigation were insignificant during both years of the study (Table 1). The maturity ratio was highest in the RF-SR and TR treatments (0.97), while it ranged between 0.94 and 0.95 in the FI and HI treatments (Table 3 ). Irrigation (continuously wet soil, with hardly any water deficits) propels the plant to vegetative growth, limiting the nutrients left in the soil for extraction during active fiber growth bolls, resulting in lower cellulose deposition (Letey and Dinar 1986).

\section{Upper quartile length by weight (UQLw)}

The UQLw denotes the length of the longest $5 \%$ of all fibers in the sample and was significantly affected by irrigation, while the PG and irrigation interaction with PG were insignificant (Table 1). As seen in Table 3, the UQLw ranged from $32.3 \mathrm{~mm}$ to $33.8 \mathrm{~mm}$, and both the $\mathrm{HI}$ and FI treatments had significantly higher UQLw than the RF cotton (Table 3).

\section{Seed composition parameters Protein}

We measured protein from the cottonseeds from both years of the study (Table 1) and found that irrigation had a significant adverse effect on seed protein accumulation, but the PG did not impact the protein levels. Both the RF treatments (SR: $24.8 \%$ and TR: $23.55 \%$ ) accumulated significantly more protein than the FI (SR: 23.1\% and TR: $22.8 \%$ ) and HI (SR: $23.2 \%$ and TR: $22.8 \%$ ) treatments (Fig. 2a). 
Table 3 Fiber quality characteristics of full irrigated (FI) and half irrigated (HI) and rain-fed (RF) cotton grown in Dundee silt loam with single-row (SR) and twin-row (TR) planting geometries estimated by advanced fiber information systems (AFIS)

\begin{tabular}{|c|c|c|c|c|c|c|c|c|c|c|c|c|c|}
\hline \multirow[t]{2}{*}{ Treatment } & \multirow[t]{2}{*}{ Planting geometry } & \multicolumn{3}{|c|}{$\mathrm{Nep} /\left(\mathrm{g}^{-1}\right)$} & \multicolumn{3}{|c|}{ Fiber length $(\mathrm{Ln}) / \mathrm{mm}$} & \multicolumn{3}{|c|}{$\mathrm{SFC}(\mathrm{n}) / \%$} & \multicolumn{3}{|l|}{ VFM / \% } \\
\hline & & 2018 & 2019 & Mean & 2018 & 2019 & Mean & 2018 & 2019 & Mean & 2018 & 2019 & Mean \\
\hline \multirow[t]{2}{*}{$\mathrm{Fl}$} & SR & $155.2 \mathrm{~b}$ & $132.5 \mathrm{~b}$ & $143.9 \mathrm{~b}$ & 23.88 & 23.11 & $23.5 \mathrm{a}$ & 22.8 & 21.9 & 22.4 & $3.15 \mathrm{a}$ & $8.14 a$ & $5.65 a$ \\
\hline & TR & $168.9 \mathrm{ab}$ & $141.5 \mathrm{a}$ & $155.2 \mathrm{a}$ & 23.37 & 23.62 & $23.5 \mathrm{a}$ & 22.5 & 22.1 & 22.3 & $3.12 \mathrm{a}$ & $8.24 \mathrm{a}$ & $5.68 \mathrm{a}$ \\
\hline \multirow[t]{2}{*}{$\mathrm{HI}$} & SR & $176.4 \mathrm{a}$ & $146 \mathrm{a}$ & $161.2 \mathrm{a}$ & 23.62 & 23.11 & $23.4 \mathrm{a}$ & 23.6 & 22.5 & 23.0 & $2.61 \mathrm{~b}$ & $7.80 \mathrm{a}$ & $5.21 \mathrm{~b}$ \\
\hline & TR & $168.4 \mathrm{ab}$ & $132.6 \mathrm{~b}$ & $150.5 b$ & 23.62 & 23.11 & $23.4 \mathrm{a}$ & 22.5 & 23.3 & 22.9 & $2.62 \mathrm{~b}$ & $7.70 \mathrm{a}$ & $5.16 b$ \\
\hline \multirow[t]{2}{*}{ RF } & SR & $102.6 \mathrm{C}$ & $84.5 \mathrm{C}$ & $93.6 \mathrm{c}$ & 21.59 & 21.08 & $21.3 b$ & 21.5 & 20.8 & 21.3 & $2.50 \mathrm{~b}$ & $6.84 a$ & $4.67 \mathrm{C}$ \\
\hline & TR & $95.8 \mathrm{C}$ & $88.6 \mathrm{C}$ & $92.2 \mathrm{C}$ & 21.84 & 21.34 & $21.6 b$ & 20.6 & 20.5 & 20.5 & $2.66 \mathrm{~b}$ & $5.82 \mathrm{a}$ & $4.24 c$ \\
\hline \multirow[t]{2}{*}{ Treatment } & Planting geometry & \multicolumn{3}{|l|}{ SFCn } & \multicolumn{3}{|c|}{ UQLw / mm } & \multicolumn{3}{|c|}{ Maturity ratio } & \multicolumn{3}{|c|}{ Fineness / mtex } \\
\hline & & 2018 & 2019 & Mean & 2018 & 2019 & Mean & 2018 & 2019 & Mean & 2018 & 2019 & Mean \\
\hline \multirow[t]{2}{*}{$\mathrm{Fl}$} & SR & $8.15 \mathrm{a}$ & $7.1 \mathrm{ab}$ & $7.63 c$ & $33.8 \mathrm{a}$ & $32.8 \mathrm{bcd}$ & $33.3 \mathrm{a}$ & $0.94 \mathrm{~b}$ & $0.94 \mathrm{C}$ & $0.94 \mathrm{C}$ & $166.2 \mathrm{C}$ & $176.5 \mathrm{bc}$ & $171.4 \mathrm{~b}$ \\
\hline & TR & $7.17 \mathrm{ab}$ & $6.8 \mathrm{ab}$ & $6.99 a$ & $33.5 \mathrm{ab}$ & $32.7 \mathrm{bcd}$ & $33.3 \mathrm{a}$ & $0.93 c$ & $0.95 \mathrm{~b}$ & $0.94 \mathrm{C}$ & $167.8 \mathrm{C}$ & $173.4 \mathrm{C}$ & $170.6 \mathrm{~b}$ \\
\hline \multirow[t]{2}{*}{$\mathrm{HI}$} & SR & $7.41 \mathrm{ab}$ & $6.4 \mathrm{~b}$ & $6.91 \mathrm{a}$ & $33.5 \mathrm{ab}$ & $32.5 \mathrm{~cd}$ & $33.0 \mathrm{~b}$ & $0.95 \mathrm{~b}$ & $0.95 \mathrm{~b}$ & $0.95 \mathrm{~b}$ & $172.5 \mathrm{~b}$ & $178.3 \mathrm{~b}$ & $175.4 \mathrm{~b}$ \\
\hline & TR & $7.10 \mathrm{ab}$ & $6.4 \mathrm{~b}$ & $6.75 \mathrm{~b}$ & $33.8 \mathrm{a}$ & $32.5 \mathrm{~cd}$ & $33.3 \mathrm{a}$ & $0.93 c$ & $0.95 \mathrm{~b}$ & $0.94 \mathrm{c}$ & $173.1 \mathrm{~b}$ & $177.6 \mathrm{~b}$ & $175.4 b$ \\
\hline \multirow[t]{2}{*}{ RF } & SR & $6.62 c$ & $7.1 \mathrm{ab}$ & $6.86 a$ & $33.0 \mathrm{abc}$ & $32.3 \mathrm{~d}$ & $32.8 \mathrm{C}$ & $0.96 \mathrm{a}$ & $0.97 \mathrm{a}$ & $0.97 \mathrm{a}$ & $182.2 \mathrm{a}$ & $184.7 \mathrm{a}$ & $183.5 \mathrm{a}$ \\
\hline & TR & $6.35 c$ & $6.8 \mathrm{ab}$ & $6.58 \mathrm{~d}$ & $32.8 \mathrm{bc}$ & $32.3 \mathrm{~d}$ & $32.6 \mathrm{~d}$ & $0.97 \mathrm{a}$ & $0.97 \mathrm{a}$ & $0.97 \mathrm{a}$ & $185.4 \mathrm{a}$ & $186.8 \mathrm{a}$ & $186.1 \mathrm{a}$ \\
\hline
\end{tabular}

Means in each column followed by the same letter or letters are not statistically different by LSD means $(P \leq 0.05)$

VFM visible foreign matter, SFCn short fiber content by number, UQLw upper quartile length by weight

\section{Oil}

Seed oil content was significantly affected by irrigation in both years (Table 1), while PG had no impact on oil accumulation. The average oil content in rain-fed treatments was $2.2 \%$ higher than that of $\mathrm{HI}$ and FI treatments in 2018 and 5.4\% higher in 2019 (Fig. 2b).

\section{Fiber}

Seed fiber plays a vital role in meeting the dietary fiber requirements of animals, as most of the seeds after gossypol extraction are fed to animals in a cake form. In this study, neither irrigation nor PG had any impact on seed fiber. The seed fiber values ranged from 20.2 to 23.1\% (Fig. 2c).

\section{Discussion}

The average lint yields in the irrigation and PG combinations in this study were $1779 \mathrm{~kg} \cdot \mathrm{hm}^{-2}$ in FI-SR, $2029 \mathrm{~kg} \cdot \mathrm{hm}^{-2}$ in FI-TR, $1803 \mathrm{~kg} \cdot \mathrm{hm}^{-2}$ in HI-SR, 2082 $\mathrm{kg} \cdot \mathrm{hm}^{-2}$ in HI-TR, $1573 \mathrm{~kg} \cdot \mathrm{hm}^{-2}$ in RF-SR, and 1788 $\mathrm{kg} \cdot \mathrm{hm}^{-2}$ in RF-TR (Pinnamaneni et al. 2020). We demonstrated that FI would not result in any yield advantage over alternate row irrigation: TR-PG produced $10.6 \%$ in 2018 and $17.6 \%$ in 2019 . The lack of irrigation response is most likely due to excess water around the root zone, which is caused by heavy precipitation events following irrigation. This situation will presumably cause hypoxia, nutrient leaching and lower water uptake resulting in the redistribution of energy allocation within the plant that leads to higher vegetative growth at the expense of reproductive growth, i.e., flowering and boll formation
(Feng et al. 2014; Letey and Dinar 1986; Wanjura et al. 2002). The higher vegetative growth and lower reproductive growth results under these conditions are understandable, as cotton was initially a perennial species, and abiotic stress (hypoxia and lower water and nutrient uptake) can trigger more vegetative growth. These growth results coincided with boll formation and boll development stages in July and August (Fig. 1b). Another study conducted in the MS Delta demonstrated that the growth and development of individual cotton plants would slow to some degree under reduced irrigation, and fiber and seed composition were affected accordingly (Bellaloui et al. 2015).

We measured the fiber quality parameters using both the HVI and the AFIS. We discovered that irrigation rates (FI, HI, and $\mathrm{RF}$ ) significantly impacted these parameters, but the PG (SR and TR) only influenced the micronaire and nep count. For some parameters like $+\mathrm{b}$, $\mathrm{Rd}$, UHML, VFM, and maturity ratio, the year-wise response appears inconsistent due to the variations in GDDs, precipitation, and solar radiation from July to September, the months that coincide with boll development and maturation. In this study, micronaire was $11 \%$ higher in 2018 and 12\% higher in 2019 than the average of the HI and FI treatments. The acceptable level of micronaire was between 3.5 and 4.9. The best level of micronaire ranges from 3.7 to 4.2 , and the quality goes down when it is $>4.9$ or $<3.5$. In our study, the micronaire range varied from 3.95 to 4.91 , and Dağdelen et al. (2009), Feng et al. (2014), and Zhang et al. (2016) reported similar results. The TR geometry produced up to 

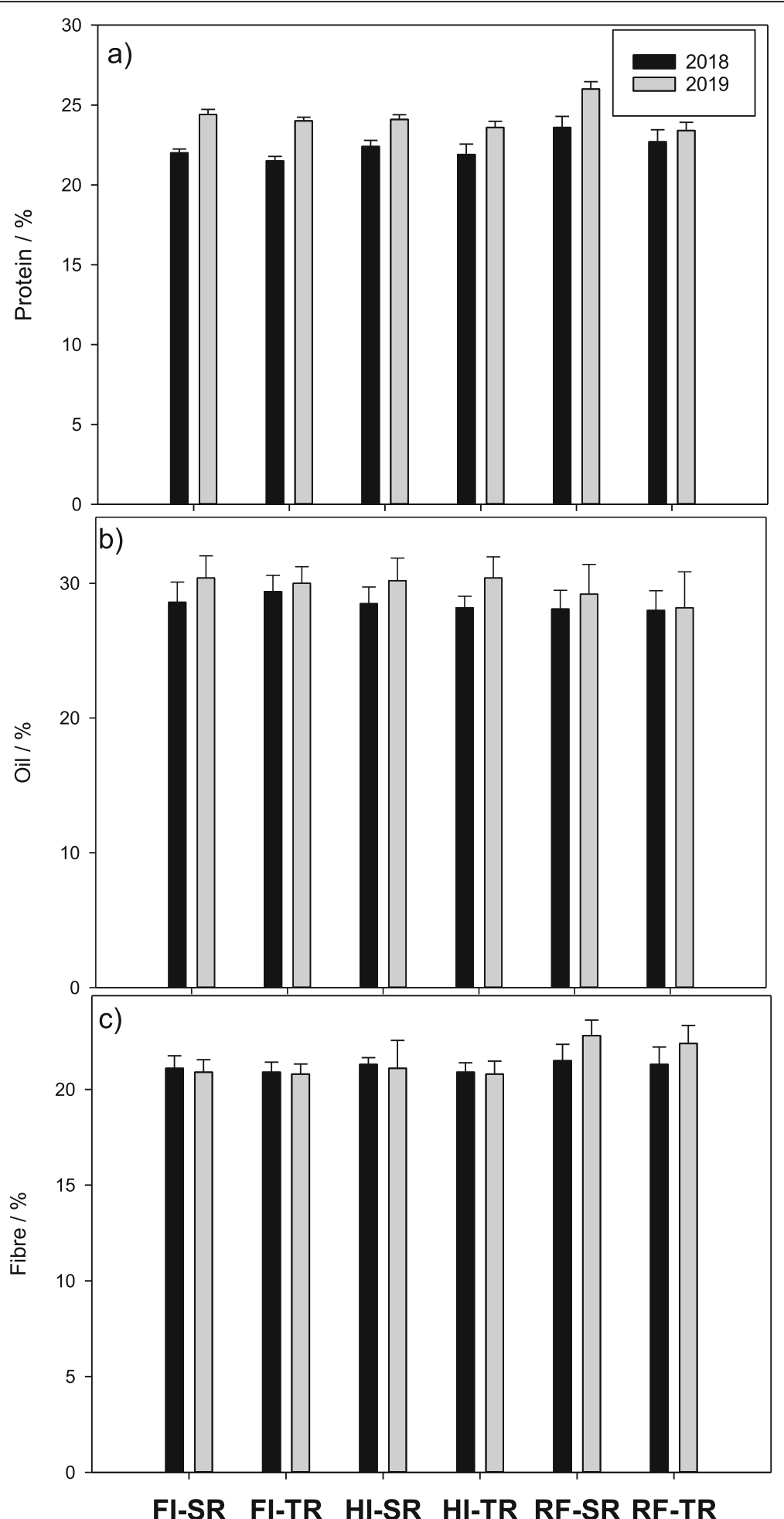

Irrigation and planting geometry treatments

Fig. 2 Effect of irrigation and planting geometry on seed composition traits in 2018 and 2019 seasons a) protein b) oil c) fiber. Fl: full irrigation, HI: half irrigation, RF: rain-fed; SR: Single-row and TR: twin-row 
$6 \%$ greater micronaire while nep count was lower in the TR arrangement, with some degree of inconsistency. These observations are similar to the findings of Reddy et al. (2009), Stephenson et al. (2011), and Feng et al. (2014). In a 2-year study conducted in Louisiana, Stephenson et al. (2011) showed that the micronaire, strength, and Rd were higher, and nep count and seed coat nep count were lower for $38-\mathrm{cm}$ twin rows than for 102-cm solid rows. During the fiber developmental stages of the cotton plant, factors, such as weather conditions, nutrient and water stresses, defoliant application time, and cultivar-type, can all impact micronaire (Hake et al. 1990). Overall, we did not find PG differences for length, uniformity, trash or $+b$ using the HVI. Similarly, we did not find PG differences for fineness, immature fiber content, maturity ratio, SFCn and UQLw using the AFIS. For both testing methods, there was some inconsistency between years. Fiber length and uniformity were higher in the $\mathrm{HI}$ and FI over the RF treatment, while fineness and maturity ratio were higher in the RF treatment, which agrees with the findings of Feng et al. (2014), Dağdelen et al. (2009) ,and Pettigrew (2004). Irrigated cotton had higher SFC than the RF treatments, contrary to the observations of Sui et al. (2017), who used a cotton picker for sampling compared with hand picking in the current study. Differences in irrigation and precipitation can explain this SFC result during boll development maturation, which drives the plant towards the vegetative phase, resulting in lower cellulose deposition in the developing fibers, further supported by the inverse relationship of irrigation with the maturity ratio in this study. Dağdelen et al. (2009), Feng et al. (2014), and Wanjura et al. (2002) reported similar results. A 2year study in Lubbock, TX, indicated that irrigation increased the SFCn, in contrast to the findings of the current study (Feng et al. 2014). This inconsistency in results is probably due to establishing a better water balance between plant evapotranspiration demands and irrigation water applied. The reduced fiber strength in this study under rain-fed conditions confirms earlier observations of the involvement of carbohydrate and energy metabolisms in fiber development and carbon skeletons to synthesize cell wall polysaccharides and fatty acids (Yang et al. 2008). Moisture stress negatively impacts the formation of the actin cytoskeleton that triggers the secondary cell wall synthesis, a key component in determining the fiber strength (Wang et al. 2010).

Cottonseed and its products are used as animal feed and are in high demand by the dairy and other foodrelated industries. Pettigrew and Dowd (2012) have documented that cottonseed and other products produced by the seeds can differ by cultivar variety, planting date, and irrigation design. In our study, protein accumulation was negatively affected by irrigation, which significantly impacted seed oil content. Irrigation did not affect seed fiber. The PG type did not influence any of the three seed composition traits studied here. However, most often, protein and oil accumulation are genotypedependent. These observations confirm the Pettigrew and Dowd (2012) findings and the Bellaloui and Turley (2013) findings.

The availability of water in the soil primarily determines the ability of individual cells within a plant to expand. Root tips growing through the soil and fibers elongating on seed coats in the bolls are both parts of the plant that are growth-limited by access to water in the soil. Apart from limiting plant growth, soil water constraints can trigger hormonal differences, particularly during reproductive growth stage, resulting in senescence in fruiting bodies such as squares and bolls. Efficient irrigation management involves reducing moisture stress at critical growth stages, allowing plants to have the maximum capacity to initiate, retain, grow, and produce mature bolls, which results in addressing the dual objectives of achieving higher fiber quality and better seed composition.

\section{Conclusion}

This study demonstrates that: (i) environmental conditions such as precipitation and solar radiation during boll development and cracking stages can heavily impact fiber quality and seed composition in cotton; (ii) among irrigation and PG, irrigation had a more significant effect on fiber quality and seed composition; (iii) irrigation may not always result in better fiber quality with desirable seed composition; (iv) irrigation had an inverse relationship with protein accumulation and a limited positive effect on oil content, but irrigation did not affect seed fiber content; (v) the HI-TR system is economical as there is no compromise on either lint yield or quality. Both fiber quality and seed composition parameters vary more significantly with irrigation treatment than differing PG treatments at critical stages of boll development and seed maturation.

\section{Abbreviations \\ AFIS: Advanced fiber information system; ANOVA: Analysis of variance; GDD: Growing degree days; Fl: Full irrigation; HI: Half irrigation; HVI: High volume instrument; LSD: Least significant difference; MS: Mississippi; NIRS: Near Infrared Spectroscopy; RF: Rain-fed; SFCn: Short fiber content by Number; SR: Single row; TR: Twin row; UHML: Upper half mean length; UQLw: Upper quartile length by weight; VFM: Visible foreign matter}

\section{Acknowledgements}

We would like to acknowledge the support of the USDA-AMS at Dumas, AR for HVI analysis and Fiber and Biopolymer Research Institute, Texas Tech University, Lubbock, TX for AFIS analysis. Mention of trade names or commercial products in this article is solely for the purpose of providing specific information and does not imply recommendation or endorsement by the USDA. USDA is an equal opportunity employer. 


\section{Authors' contributions}

Pinnamaneni SR collected most of the data, performed data analysis and wrote manuscript. Anapalli SS, Sui R and Reddy KN contributed to designing the experiment and manuscript editing. Bellaloui $\mathrm{N}$ performed seed composition analysis. The authors read and approved the final manuscript.

\section{Funding}

Funding was made available through the USDA-ARS project No: 606613000-005-00D.

\section{Availability of data and materials}

Review of data is available upon request.

\section{Ethics approval and consent to participate}

Not applicable.

\section{Consent for publication}

All Authors have reviewed the manuscript and given consent for publication.

\section{Competing interests}

None of the authors have any competing interests within the scope of this experiment and its publication.

\section{Author details}

'USDA-ARS, Sustainable Water Management Research Unit, Stoneville, MS 38776, USA. ${ }^{2}$ USDA-ARS, Crop Genetics Research Unit, Stoneville, MS 38776, USA. ${ }^{3}$ USDA-ARS, Crop Production Systems Research Unit, Stoneville, MS 38776, USA.

Received: 14 September 2020 Accepted: 29 December 2020 Published online: 20 January 2021

\section{References}

Arieli A. Whole cottonseed in dairy cattle feeding: a review. Anim Feed Sci Technol. 1998:72:97-110.

Balkcom KS, Reeves DW, Shaw JN, et al. Cotton yield and fiber quality from irrigated tillage systems in the Tennessee Valley. Agron J. 2006;98:596-602. https://doi.org/10.2134/agronj2005.0219

Bartimote T, Quigley R, Bennett JM, et al. A comparative study of conventional and controlled traffic in irrigated cotton: II. Economic and physiological analysis. Soil Tillage Res. 2017;168:133-42. https://doi.org/10.1016/j.still.2016.12.009.

Basal H, Dagdelen N, Unay A, et al. Effects of deficit drip irrigation ratios on cotton (Gossypium hirsutum L.) yield and fibre quality. J Agron Crop Sci. 2009;195:19-29.

Bellaloui N, Stetina SR, Turley RB. Cottonseed protein, oil, and mineral status in near-isogenic Gossypium hirsutum cotton lines expressing fuzzy/linted and fuzzless/linted seed phenotypes under field conditions. Front Plant Sci. 2015; 6:137. https://doi.org/10.3389/fpls.2015.00137.

Bellaloui N, Turley RB. Effects of fuzzless cottonseed phenotype on cottonseed nutrient composition in near isogenic cotton (Gossypium hirsutum L.) mutant lines under well-watered and water stress conditions. Front Plant Sci. 2013;4: 516. https://doi.org/10.3389/fpls.2013.00516

Bowman RK, Ethridge DE. Characteristic supplies and demands in a hedonic framework: US market for cotton fiber attributes. Am J Agric Econ. 1992;74: 991-1002.

Boykin JC, Reddy KN. The effects of narrow-row and twin-row cotton on fiber properties. J Cotton Sci. 2010;14:205-11.

Dağdelen N, Başal H, Yılmaz E, et al. Different drip irrigation regimes affect cotton yield, water use efficiency and fiber quality in western Turkey. Agric Water Manag. 2009;96:111-20.

Darawsheh M, Chachalis D, Aivalakis G, Khah EM. Cotton row spacing and plant density cropping systems II. Effects on seedcotton yield, boll components and lint quality. J Food Ag Environ. 2009;7:262-5.

Desclaux D, Roumet P. Impact of drought stress on the phenology of two soybean (Glycine max L. Merr) cultivars. Field Crop Res. 1996;46:61-70. https:// doi.org/10.1016/0378-4290(95)00086-0.

Dowd MK. Seed. in Fang DD, Percy RG, editors. Cotton, vol. 57. 2nd ed. Madison: American Society of Agronomy, Inc., Crop Science Society of America, Inc., and Soil Science Society of America, Inc; 2015. p. 745-82. https://doi.org/10. 2134/agronmonogr57.2013.0032 .
Feng L, Mathis G, Ritchie G, et al. Optimizing irrigation and plant density for improved cotton yield and fiber quality. Agron J. 2014;106:1111-8. https:// doi.org/10.2134/agronj13.0503.

Ge $Y$, Thomasson JA, Sui R, et al. Spatial variation of fiber quality and associated loan rate in a dryland cotton field. Precis Agric. 2008;9:181-94.

Hake K, Mayfield B, Ramey H, et al. Producing quality cotton. Cotton physiology education program. Memphis: National Cotton Council; 1990.

Kebede H, Fisher DK, Sui R, et al. Irrigation methods and scheduling in the Delta region of Mississippi: current status and strategies to improve irrigation efficiency. Am J Plant Sci. 2014;05:2917-28. https://doi.org/10.4236/ajps.2014.520307.

Letey J, Dinar A. Simulated crop-water production functions for several crops when irrigated with saline waters. Hilgardia. 1986;54:1-32.

Pettigrew WT. Moisture deficit effects on cotton lint yield, yield components, and boll distribution. Agron J. 2004;96:377-83. https://doi.org/10.2134/agronj2004. 0377.

Pettigrew WT. Impact of varying planting dates and irrigation regimes on cotton growth and lint yield production. Agron J. 2010;102:1379-87.

Pettigrew WT, Dowd MK. Varying planting dates or irrigation regimes alters cottonseed composition. Crop Sci. 2011;51:2155-64.

Pettigrew WT, Dowd MK. Molecular biology and physiology: interactions between irrigation regimes and varieties result in altered cottonseed composition. J Cotton Sci. 2012:16:42-52.

Pinnamaneni S, Anapalli SS, Fisher DK, et al. Irrigation and planting geometry effects on cotton (Gossypium hirsutum L.) yield and water use. J Cotton Sci. 2020;24:87-96

Plumblee MT, Dodds DM, Krutz $\sqcup$, et al. Determining the optimum irrigation schedule in furrow irrigated cotton using soil moisture sensors. Crop Forage Turfgrass Manag. 2019;5:1-6. https://doi.org/10.2134/cftm2018.06.0047.

Reddy KN, Boykin JC. Weed control and yield comparisons of twin- and singlerow glyphosate-resistant cotton production systems. Weed Technol. 2010;24: 95-101. https://doi.org/10.1614/wt-d-09-00044.1.

Reddy KN, Burke IC, Boykin JC, et al. Narrow-row cotton production under irrigated and non-irrigated environment: plant population and lint yield. J Cotton Sci. 2009;13(2):48-55.

Roth G. Economic, environmental and social sustainability indicators of the Australian cotton industry, vol. 121; 2010. http://27.111.91.222/xmlui/ bitstream/handle/1/321/3_03_09_Roth.pdf? sequence=1\&isAllowed=y. Accessed 12 Aug 2020

Stansbury MF, Pons WA, Den Hartog GT. Relations between oil, nitrogen, and gossypol in cottonseed kernels. J Am Oil Chem Soc. 1956;33:282-6.

Stephenson DO, Barber LT, Bourland FM. Agronomy and soils: effect of twin-row planting pattern and plant density on cotton growth, yield, and fiber quality. J Cotton Sci. 2011;15:243-50.

Sui R, Byler RK, Delhom CD. Effect of nitrogen application rates on yield and quality in irrigated and rainfed cotton. J Cotton Sci. 2017;21:113-21.

USDA- NASS. Mississippi cotton county estimates. 2019. https://www.nass.usda. gov/Statistics_by_State/Mississippi/Publications/County_Estimates/2018/18 MS cotton all.pdf. Accessed 1 Mar 2020

Wang L, Li XR, Lian H, et al. Evidence that high activity of vacuolar invertase is required for cotton fiber and Arabidopsis root elongation through osmotic dependent and independent pathways, respectively. Plant Physiol. 2010;154: 744-56. https://doi.org/10.1104/pp.110.162487.

Wanjura DF, Upchurch DR, Mahan JR, et al. Cotton yield and applied water relationships under drip irrigation. Agric Water Manag. 2002;55:217-37. https://doi.org/10.1016/S0378-3774(01)00175-5.

Wilcox JR, Shibles RM. Interrelationships among seed quality attributes in soybean. Crop Sci. 2001:41(1):11-4.

Witt TW, Ulloa M, Schwartz RC, et al. Response to deficit irrigation of morphological, yield and fiber quality traits of upland (Gossypium hirsutum L.) and Pima (G. barbadense L.) cotton in the Texas High Plains. Field Crop Res. 2020:249:107759. https://doi.org/10.1016/j.fcr.2020.107759.

Yang YW, Bian SM, Yao Y, et al. Comparative proteomic analysis provides new insights into the fiber elongating process in cotton. J Proteome Res. 2008;7: 4623-37. https://doi.org/10.1021/pr800550q.

Zhang D, Luo Z, Liu S, et al. Effects of deficit irrigation and plant density on the growth, yield and fiber quality of irrigated cotton. Field Crop Res. 2016;197:19. https://doi.org/10.1016/j.fcr.2016.06.003. 